\title{
IAMJ
}

INTERNATIONAL

AYURVEDIC

MEDICAL JOURNAL

\section{A REVIEW ARTICLE ON SHATAPONAKA BHAGANDARA}

\section{$\underline{\text { Radhika Pachamalai }}{ }^{1}$, Narmada M.G $^{2}$}

${ }^{1}$ PG Scholar, ${ }^{2}$ Professor,

Dept. Of Shalya Tantra, Govt. Ayurvedic Medical College Bengaluru, Karnataka, India

Corresponding Author: drradhikap29@gmail.com

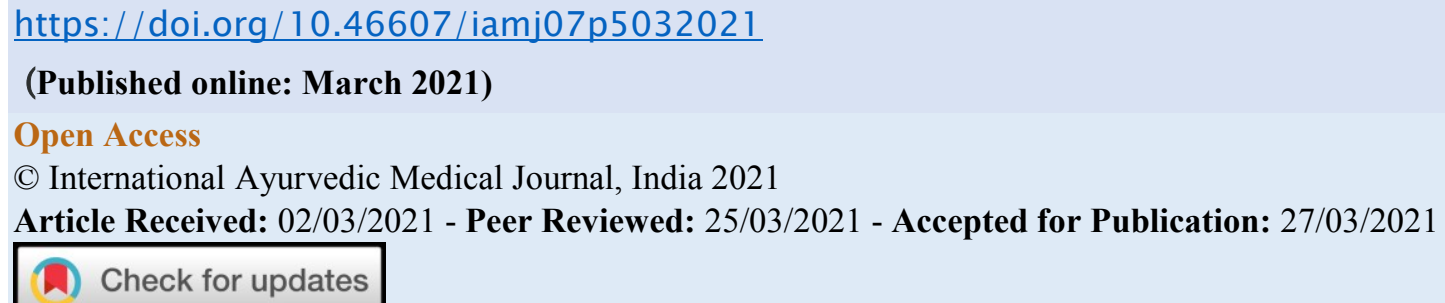

\begin{abstract}
Bhagandara disease has been explained in detail by Sushruta highlighting it as one among the Ashtamahagada and out of five types of Bhagandara, Sambukavarta considered as Asadhya, remaining four are Kruchrasadhya. Bhagandara is a track lined by unhealthy granulation tissue, pus discharge and can be correlated with Fistula-in-Ano. Shataponaka (Vataja) Bhagandara which is having Nidana, Samprapthi, Purvarupa, Rupa. Acharya Sushruta explained Shastra Karma with 4 unique incisions to avoid complication. The same procedure can be correlated to fistulotomy and fistulectomy which is told in Fistula-in-ano. Even though Ksharasutra popularly used in Bhagandara, Shastrakarma plays main role in Shataponaka Bhagandara. Conditions are like fistula-in-ano with multiple opening, Tubercular fistula-in-ano, Hidradenitis suppuritiva, Crohn's disease with fistula-in-ano, Uncontrolled diabetic patient with multiple fistula-in-ano, Perianal actinomycosis can be included under Shataponaka Bhagandara. In order to avoid multiple incisions and to enhance quick healing these incisions can be used in multiple track.
\end{abstract}

Keywords: Shataponaka bhagandara, Tuberculosis fistula-in-ano, Hidradenitis suppuritiva, Sitz bath, Incisions.

\section{INTRODUCTION}

In Ayurveda texts we have brief information about 'Bhagandara', its literary meaning of 'Bhaga' denotes the structures around Guda (anus) including Yoni and Basti, 'Darana' word means tear of surface causing pain. Bhagandara (fistula in ano) is one among commonest ano-rectal disease, which exists in human being from pre-Vedic and post $\mathrm{Ve}$ dic period which evidences in Samhitas regarding existence and treatment of the disease. Sushruta has explained Nidana (Aetiology), Poorvarupa (Pro- 
dromal features), Samprapti (Pathogenesis), Bheda (Types), Lakhshana (Clinical features), Sadhyaasadhyas (Prognosis), Upadrava (complication), Pathaapathya (Salutary and unsalutary) and Chikitsa (Treatment) in his Sushruta Samhita. In case of Shataponaka Bhagandara its management by 4 unique incisions.

Bhagandara Pidaka a swelling occurring two Angula (fingers) around the Guda (anus) which is Goodhamoola (deep rooted) and is accompanied with Ruk (pain) Jwara (fever) is known as Bhagandara Pidaka. ${ }^{(1)}$ Bhagandara Classified depending upon Dosha involvement ${ }^{(2)}$

1. Shataponaka (Vataja) In this Shata is hundred, Ponaka is opening. Pidaka with multiple openings like Chalanika (Sieve), fistula and rectal sinuses have multiple opening.

2. Ustragreeva (Pittaja) word denotes neck of camel, this is red, thin and raised like camel's neck.

3. Parisravi (Kaphaja) continuous discharge from wound. Where Vata carries vitiated Kapha to Guda.

4. Sambukavarta (Vata, Pitta, Kapha) 'Ridges of a Conchshell' suggests that the track is curved and deep. Pidaka (Boil) is large and elevated and has Padangushta Pramana (Tip of the great toe size).

5. Unmargi (Agantuja) caused by trauma with no Dosha involvement. Asthi shalya (Bony foreign body) or any Shalya ingested with Ahara (food), reaching Guda causing trauma to develop this Bhagandara.

According to Ashtanga Sangraha and Ashtanga Hridayam $^{(3)}$ there are 8 types of Bhagandara. Among these five types explained as above same described by Sushruta and remaining three are: 1. Parikshepi Bhagandara (Vata Pittaja) Tamara var$n a$ (white color) Pidaka associated with burning sensation, pain in perineal region. 2.Ruju Bhagandara (Vata Kaphaja) forms straight track. Which is whitish or slightly blackish discharge and difficult to deal. 3. Arsho Bhagandara (kapha Pittaja) reaching the base of Arshas (Haemorroid) forming Shopha which is whitish in colour. Causing burning sensation, itching and pain. It suppurates very quickly to discharge continuously. This track is seen at the base of Arshas.
According to Sushrutha depending upon opening of Bhagandara Nadi 1. Arvachina means Antarmukhi (Blind internally) 2. Parachina means Bahirmukhi (Blind externally).

Shataponaka Bhagandara: Nidana are due to indulgence in unsalutary diets and habits, Vata Prakupita, Sannivrutta (condensed) and gets Shribhutha (localized) around Guda in one or two Angulas, involves the Mamsa, Shonitha gives rise to specific type of Aruna Varna (Black color) Pidaka and Toda (pain like pin and needles prick). If it remains untreated, suppuration results(anorectal abscess), which is close proximity to the Mutrashaya (urinary bladder) the Vrana (wound) is always Praklinna (moist) Shataponakavad Anumukhashchidrairaapooryatai (full of multiple small holes like that in a sieve) from those minute holes copious, clear or foamy discharge flows out continuously and there is (Taadya)whipping, (Bhidya) tearing, (Chidya) biting and (Soochi) pricking pain in the wound and there is also (Avadeerya)splitting sensation of the anus. If neglected; flatus, urine, faeces and semen start coming out of those openings; such a Bhagandara is called Shataponaka. ${ }^{(4)}$

Management of Bhagandara: Patient afflicted with Bhagandara Pidaka (ano-rectal abscess) should be treated in its yet to suppurated stages by the eleven procedures beginning with Apatharpana (fasting), Alepa (application of paste), Parisheka (spraying), Abhyanga (anointing), Swedana (sudation), Vimlapana (gentle massage by the fingers), Upanaha (application of poultice), Pachana (induction of suppuration), Visravana (blood letting), Sneha paana (internal oleation), Vamana (emesis) and Virechana (purgation). Once Pidaka becomes Pakva, the patient should be made Snighdha, Swinna by Avagaha (immersion in warm water), patient made to lie on bed in lithotomy position as told in Arsha chikitsa and Vaidya should examine the externally or internally openings of Bhagandara. The Fistula opening is located and Eshani (Probe) is introduced into the track and Shashtra paathyeth(excised). If the condition cannot be treated by Shashtra then Kshara or Agnikarma can be done. ${ }^{(5)}$ Sneha Pariseka: Vataja Vedana Anutaila Ushna (warm) Parisheka. Swedana and sitz bath: 1. Bashpa Sweda: The anal region anointed with oil and patient made to sit over basin, which is covered with Chidrasharavika (lid 
having an aperture) emitting steam and contains Vatagnaushadhi 2.Nadi Sweda (Tubular sudation): Patient in recumbent position Swedana is given. 3.Avagaha Sweda: Patient immersed (to the waist) in Ushnodaka for Vedana Shamaka (Pain pacifies). 4.Upanaga Sweda: In case of Vatakaphaja Vedana. Management of Shataponaka Bhagandara should take incision of Nadi (track) which is interconnecting in external opening and after it heals up the remaining one should be taken up for operation. Fistula is excised. Complications: The surgeon when excises unconnected tracks by one continuous incision, causes extensive wound and anus being torn open. From this passage faeces and urine comes out. Shataponaka bhagandara's different incisions ${ }^{(7)} 1$. Langalaka: "Dwabhyam Samabhyam Paarshvabhyam", incision having two arms extending on either side. Like T shaped incision. 2. Ardha Langalaka: "Hrusvamekataram", similar incision with one arm. Like L shaped incision. 3. Sarvatobhadraka: "Mandalangkushasadrusha", incision surrounding the anal canal on all four side, except the perineal raphe. Like Circular shaped incision. 4. Gothirthaka: "Gomutragathisadrusha", cow passing urine during walking then the pattern of urine on ground. Semicircular or "S" shaped incision. Paschat Karma of Bhagandara Chikitsa ${ }^{(8)}$ Swedana dravyas to reduce Ruja (pain), to stop Srava (discharge) are: Krushara (Gruel prepared with rice, black gram and sesame), Payasa (rice cooked with milk and sweetened), Mamsa (Meat), Kashaya, Nadi Sweda (Tubular sudation). Later Paana (Drink) and Parisheka. By these procedure Vin (faeces), Mutra (urine) comes out through their natural passages and other Upadrava are undoubtedly cured.
According to Vagbhatta ${ }^{(2)}$ :Vataja Pidaka features Shyava, Aruna, Toda, Bedha, Sphurana and Ruk. Shataponaka Bhagandara with Anumuka Chidra (minute opening) like Chalani (sieve of water can). Characters of discharge (Srava): Accham (abounded), Тапu (thin), Phenasamyutham (along with froth). Shataponaka management by Nadi Bedana is done by interconnecting one after the other to make it a single Nadi Patayeth (excise) it completely. So that previous incision heals faster. In order to avoid recurrence.

According to Bhavaprakasha, Madavakara of Madava Nidana and Sri Vaidya Sodala of Gada Nigraha ${ }^{(9),(10),(11)}$ Shataponaka Nidana: Because of excessive consumption of Kashaya(Decoction), Ruksha Ahara (Dry food) leads to Vata aggravation causing Pidaka in ano-rectal region. If it is neglected, it undergoes suppuration and is associated with severe pain and frothy red discharge. There may be multiple openings through which urine, faeces and semen are oozed out.

The conditions can be included under Shataponaka Bhagandara are: Fistula in ano with multiple opening, Tubercular fistula-in-ano, Crohn's disease followed by fistula-in-ano, Hidradenitis suppuritiva, Uncontrolled Diabetic patient with multiple fistulain-ano, Perianal Actinomycosis.

Fistula In Ano: Fistula Latin word means reed, pipe or flute. A Fistula-in-ano is a chronic abnormal communication, usually lined to some degree by granulation tissue, which runs outwards from the anorectal lumen (the internal opening) to an external opening on the skin of the perineum or buttock(or rarely in women to the vagina).

Table 1: Aetiology of Fistula in ano ${ }^{(12)}$

\begin{tabular}{|l|l|l|}
\hline Non-specific & cryptoglandular origin & \\
\hline Specific & Ano-rectal disease & $\begin{array}{l}\text { Fissure in ano, Hemorrhoidectomy, sclerotherapy of hemorrhoids, Inflammato- } \\
\text { ry bowel disease, Crohn's disease, Ulcerative colitis, pilonidal sinus. }\end{array}$ \\
\cline { 2 - 3 } & $\begin{array}{l}\text { Infections } \\
\text { tuberculosis, Actinomycosis, lymphogranuloma venereum, Bursitis ischiadica. }\end{array}$ \\
\cline { 2 - 3 } & Malignancy & Anal carcinoma, low rectal carcinoma, blood dyscrasia Post irradiation. \\
\hline & $\begin{array}{l}\text { Penetrating injuries, Episiotomy, Surgery of the prostate, ingested foreign bod- } \\
\text { ies, instrumentation, injures due to enema. }\end{array}$ \\
\hline
\end{tabular}


Pathogenesis: Stage 1: Infection, Stage 2: Burrowing, Stage 3: Abscess formation, Stage 4: formation of secondary opening.

Clinical features predominantly this disease seen in men and middle age. 1 History of abscess burst 2 Pus discharge 3 fistula is essentially a painless condition, if the discharge ceases and pus accumulates, pain is experienced till the abscess bursts, gives immediate relief. 4 Soreness and itching of the perianal skin.

Table 2: Classification of Fistula in ano:

MILLIGAN MORGAN'S (1934) AND GOLIGER (1975)

1. Subcutaneous $(5 \%)$

2. Low anal $(75 \%)$

3. High anal (8\%)

4. Anorectal (7\%) i. Ischiorectal or Infralevator ii. Pelvirectal or Supralevator

5. Submucous or High intermuscular (5\%)

\section{Surgical Management}

1. Fistulotomy: Patient in lithotomy position, bidigital examination is made under anesthesia. A probe is inserted fistula track is laid open with scalpel blade. Done in very low level fistula. ${ }^{(12)}$

2. Fistulectomy: skin around the external opening the tissue around the fistula is filtrated with local anaesthetic agent to reduce bleeding. Probe is passed through external opening or the external opening grasped with tissue forceps or stay suture. The technique involves coring out of the fistula by diathermy cautery. Done in low anal fistula. ${ }^{(12)}$

3. Seton: A silk or linen ligature is passed across the fistula and left in place with a tie. It's done for intermediate and intersphincteric fistula. It is used prior to definite procedure like fistulectomy or advancement of flap. ${ }^{(13)}$

A) loose setons: no tension upon the encircled tissue, there is no intention of cutting tissue. Material used are setons non-absorbable, nondegenerative, comfortable. It stimulates fibrosis adjacent to the sphincter muscle and helps easy drainage of collected pus.

B) Tight or cutting setons are placed with the intention of cutting through the enclosed muscle.

Tuberculosis and Crohn's disease with Fistula in ano ${ }^{(14)}$ Features: multiple tracks of fistulain-ano, induration around the fistula is lacking, opening is ragged and flush with the surface, surrounding skin is discoloured and discharge is watery. In more than $30 \%$ of patients suffering from pulmonary tuberculosis, virulent tubercle bacilli are present in rectum.

Hidradenitis suppuritiva ${ }^{(15)}$ : It's a chronic suppurative condition of aprocrine glands of the skin in axilla/perineum/mons pubis/thighs/scrotum. Common in young obese females.

Pathogenesis: Apocrine gland duct obstruction due bacterial infection making multiple glands involvement, which is secondary infection of staphylococcus aureus, streptococci lead to skin oedema, multiple raised pustules and multiple communicating fistulae formation. Disease does not extent above dentate line on into sphincter. Sinus presentation: scarred area, discharge, skin changes, pain, tenderness and foul-smelling fluid.

Treatment: Weight reduction, proper hygiene, Antibiotics and analgesics, Incision and drainage of abscess, laying open of all communicating tracks and regular dressing, Radical local excision of entire apocrine bearing perineal skin with reconstruction using flap, Recurrence in known to occur.

\section{DISCUSSION}

In Shataponaka Bhagandara management Sushruta advocated various incision for successful results. Langalaka means plough (agricultural instrument) similar to English letter T. This incision applicable in case when two or more external opening of fistula connected to single internal opening. Example: external opening at 11 ' $\mathrm{O}$ ' clock, 1 ' $\mathrm{O}$ ' clock, 12 ' $\mathrm{O}$ ' 
clock position and all three have internal opening at 12 ' $\mathrm{O}$ ' clock position. Make incision interconnecting from 11 ' $\mathrm{O}$ ' clock to 1 ' $\mathrm{O}$ ' clock position allow it to drain pus discharges and heal. Later excise the track at 12 ' $\mathrm{O}$ ' clock position. So that whole cavity exposed, and pus drainage happens faster, and healing happens as Sadhyovrana. Ardha Langalaka: plough with one arm, English letter like "L". Example: external opening at 4 ' $\mathrm{O}$ ' clock, 5 ' $\mathrm{O}$ ' clock, 6 ' $\mathrm{O}$ ' clock position and only for 6 ' $\mathrm{O}$ ' clock external opening has internal opening at 6 ' $\mathrm{O}$ ' clock position. Make incision interconnecting from 4 ' $O$ ' clock to 6 ' $\mathrm{O}$ ' clock position allow it to drain pus discharges and heal. Later excise the track at 6 'O' clock position. Sarvatobhadraka incisions: when multiple opening around anal canal from anal verge in all direction having same cavity and internal opening. Incision made to open the full cavity and no potent space. Gothirthaka: Dalhana commentator of Sushrut Samhita give some description of Gothirthaka when a cow passing urine during walking then the pattern of urine on ground, like the Yoni of cow, on the marks that printed in mud where cow drinks water near any river or pond. In all these structures has the similarity with the semi-circular shape. The pattern of urine on ground similar to "S", that have curve which are semi-circular. Both lips of Yoni are semi-circular and both side of Khur of cow are also semi-circular. multiple external opening has small cavity we just make small semi-circular incision for quick drainage of pus, helps in avoiding injury to healthy tissue. Fig. 1 and Fig.2 Advantages of these incisions: No additional incision or excision is required so that additional scarring and recur- rence can be avoided. Result will Aesthetic and noticeably long scars can be avoided. Dispersion of tension on the scar can be expected, to reduce mechanical force on the dermis of the wound edge.

All the incision are helpful in multiple track, Vaidya should select the incision appropriately according the patient condition so that quick Shodhana(cleaning) of the track followed by Swedana procedures on wound, which helps for fast healing of wound and unwanted injury to the healthy tissue can be avoided.

In case of Tubercular Fistula in ano, Crohn's disease with Fistula in ano, Uncontrolled diabetic with multiple tracks of Fistula and Perianal actinomycosis are primary cause should be treated first.

Shataponaka Bhagandara features and treatment procedures similar to Fistula-in-ano with multiple tracks, Hidradenitis suppuritiva and excluding systemic diseases. In all this condition Shataponaka Bhagandara incision technique can be applied for the fast cleaning of tracks and quick healing.

\section{CONCLUSION}

In case of multiple form of tracks instead of Ksharasutra procedures, Shataponaka Bhagandra incision taken, therefore ramification of the track can be stopped. Further quick healing can occur so that patient can recover from the disease soon. In future clinical study can be taken on Shataponaka Bhagandara incision are Langalaka, Ardhalangalaka, Sarvatobhadraka, Gothirtaka in conditions of multiple track sinuses followed by different types of Swedana procedures on wound for Shodhana and Vedhana Shamaka.

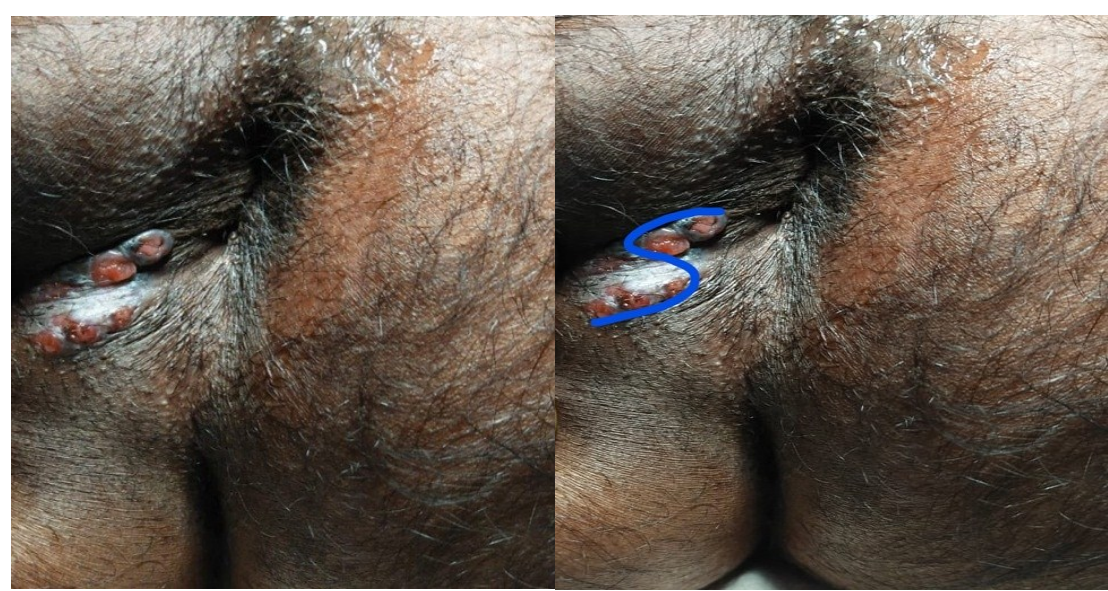

Fig 1. Shataponaka Bhagandara Fig 2. Gothirtaka (S shaped incision) 
Acknowledgment: The authors thank all faculties in the department of Shalya Tantra, Government Ayurvedic medical college, Bengaluru for their guidance and support.

\section{REFERENCES}

1. Singhal G.D and Colleagues. Susruta samhita Ancient Indian Surgery part 1. Bhagandara Nidana adhyaya, $4^{\text {th }}$ chapter. Chaukhamba Sanskrit Pratishthan. Delhi: 2007. Second edition. Pp.533

2. Acharya Sushruta, Sushrtuta Samhita of Sushruta with Nibandhasangraha Commentary of Sri Dalhanacharya \& the Nyaychandrika Panjika of Sri Gayadasacharya on Nidanasthana. Chaukhambha Sanskrit Sansthan. Varanasi. 2015.Pp. 439.

3. Acharya Vagbhata, Ashtangahrdayam of Vagbhata with the commentaries; Sarvangasundara of Arunadatta and Ayurvedarasayana of Hemadri. Chaukhamba Krishnadas Academy. Varanasi. 2018. Pp. 878

4. Singhal G.D and Colleagues. Susruta samhita Ancient Indian Surgery part 1; Bhagandara Nidana adhyaya, $4^{\text {th }}$ chapter. Chaukhamba Sanskrit Pratishthan. Delhi:2007. Second edition.Pp.530

5. Singhal G.D and Colleagues. Susruta samhita Ancient Indian Surgery part 1. Bhagandara Chikitsa adhyaya, $8^{\text {th }}$ chapter. Chaukhamba Sanskrit Pratishthan. Delhi:2007. Second edition. Verse 8/4. Pp. 240

6. Singhal G.D and Colleagues. Bhagandara Chikitsa adhyaya, $8^{\text {th }}$ chapter. Susruta samhita Ancient Indian Surgery part 1. Delhi: Chaukhamba Sanskrit Pratishthan. 2007. Second edition. Verse 8/5-18. Pp.241243

7. Acharya Sushruta, Sushrtuta Samhita of Sushruta with Nibandhasangraha Commentary of Sri Dalhanacharya \& the Nyaychandrika Panjika of Sri Gayadasacharya on Nidanasthana. Chaukhambha Sanskrit Sansthan. Varanasi: 2015. Verse 8/9-11. Pp. 439.

8. Acharya Sushruta, Sushrtuta Samhita of Sushruta with Nibandhasangraha Commentary of Sri Dalhanacharya \& the Nyaychandrika Panjika of Sri Gayadasacharya on Nidanasthana. Chaukhambha Sanskrit Sansthan. Varanasi: 2015.Verse 8/12-18. Pp. 439.

9. Bhavamishra, Bhavaprakash Nigantu, commentary by Dr. Sitarambulusu, (madhyam and uttarkhand) Vol.II, Bhagandaradhikar, chaukhamba orientalia, Varanasi, chapter, 50: 512.
10. Madavakara, Madavanidana by Vijayaraksita and Srikanthadatta. Madhukosa commentary, Vaidya Jadavji Tricumju Acharya edited, Nirnya Sagar Press. Bombay:1955. Fifth edition. Pp.272

11. Acharya Sodhala, Gadnigrah by Indradevtripathi, Vidyotini commentary, Gadnigraha-uttar chaukhamba Sanskrit series, vaaranashi, 7/10-14.

12. Russel RCG, Norman S, Williams NS, Bulsrode CJK, editors. Bailey \& Love's Short Practice of Surgery. Arnaldo- A member of Hodder Headline Group; London: 2008. 25th edition. Pp.1513

13. Ajit Nanik Singh Kukreja, Anorectal Surgery made easy. Jaypee Brothers Medical Publishers Ltd.; 2013. 1st edition. Ch.18 pg.393.

14. R.C.G. Russell, Norman S. Williams, Christopher J.K. Bulstrode, editors. Bailey \& Love's Short Practice of Surgery. Anus and Anal Canal, Fistula-inano,P. Hodder Arnold publication, London: 2004. 24th Edition, 1266.

15. Sriram Bhat M. Foreword Prakash Rao. SRB's Manual of Surgery, Jaypee brothers' medical publishers (P) Ltd. $3^{\text {rd }}$ edition. 2010. Pp.923.

\section{Source of Support: Nil Conflict of Interest: None Declared}

How to cite this URL: Radhika P \& Narmada M. G: A Review Article on Shataponaka Bhagandara. International Ayurvedic Medical Journal \{online\} 2021 \{cited March, 2021\} Available from: http://www.iamj.in/posts/images/upload/2811_2816.pdf 